loss of the memories themselves" without indicating that such matters are still under active debate. He is likewise convinced that the storage and recognition of faces is to mention that in (monkey) cortex there do appear to be single cells tuned to particular familiar faces. His interpretation of commissurotomy ("split-brain") patients also prejudges the outcome of current discussion. Contra Smith's confident assertions, there are reputable scientists who do believe that we have two brains (hemispheres) and that (in the vast majority of people) language capacity and skill is limited to one of them.

Ancestral Voices is clearly intended as a popular, "lay" book on a topic that very naturally fascinates many people well beyond the confines of the neuroscience community. All the more important, then, that a fair picture should be painted a holographic process, but does not bother

of the limits of current knowledge, and of the disagreements between those who work in the area. Professor Smith's efforts do not meet these requirements. Whitney's trenchant summary (1870) of theories of the origin of language comes to mind all too often:

No theme in linguistic science is more often and more voluminously treated than this, and by scholars of every grade and tendency; nor any, it may be added, with less profitable result in proportion to the labor expended.

If, despite Whitney's pessimism, the urge to read a book on the topic remains, I would recommend that one searched for a copy of George John Romanes' Victorian masterpiece, Mental Evolution in Man (1888).

John C. Marshall is in the Neuropsychology Unit, part of the Neuroscience Group at the Radcliffe Infirmary, Oxford $O X 26 H E$, UK.

\section{Temporal questions}

\section{James A. Secord}

The Dark Abyss of Time: The History of the Earth and the History of Nations from Hooke to Vico. By Paolo Rossi. Translated by Lydia G. Cochrane. University of Chicago Press: 1985. Pp.338. £32.25, $\$ 35$.

ANYONE familiar with the development of science in the past few decades will recognize that disciplinary boundaries are far from static. Sciences move closer to and further away from one another; they break up, disappear or regroup into new subjects and specialities. Move back 300 years, and the changes involve not only science but the whole realm of human knowledge. What, for example, do fossil ammonites have in common with Chinese writing and the Egyptian pyramids? To modern ears the question seems absurd, for these subjects now belong in very distinctive scientific specialities, and any relation between them would seem a matter of chance. But in the seventeenth century their affinity was no riddle, but a feature of intellectual life that was taken for granted. Fossils, ancient languages and relics of lost civilizations all had a place in a unified study of the past: they were "signs of time". Hence the original Italian title of Paolo Rossi's important book I Segni del Tempo, now available to a wider audience in an English translation.

The objects grouped together here were also "signs of time" in another sense, as indications that the world might be far older than was generally thought. It is difficult for readers steeped in the time-scale of modern geology to recapture the threat that seemingly limitless time posed to men of science in the late seventeenth and early eighteenth centuries. The Copernican revolution and its consequences are familiar from many historical discussions. But as Rossi notes, "there has been no such insistence, in the same way and with the same intensity, on other, no less decisive changes" - notably our perception of time. In the late seventeenth century, the direct and best testimony on the early ages of the world's history - the Bible - rendered an estimate of some few thousand years since the beginning not only intellectually respectable, but almost inescapable. By the end of the eighteenth, scholars looked down into what Buffon called "the dark abyss of time", and in advanced circles an age for the Earth of millions of years had become a distinct possibility. The Bible was being replaced as a secure source of knowledge by broken fragments of strata, old legends and cryptic languages. The old authority had provided at least the possibility of a single coherent narrative for the history of the world; the new ones could only be deciphered piecemeal and with difficulty.

As Rossi demonstrates, this change held major consequences for the organization of knowledge. In Genesis, the world commenced in the space of a few days. This meant that the history of the Earth and the history of man could be studied as one subject, for the two histories were almost precisely coextensive. This is a basic point, but one all too often set aside by those concerned with finding the roots of modern scientific disciplines. For instance, Robert Hooke, John Woodward, William Whiston and Thomas Burnet are familiar names in the history of geology. Rossi shows that their writings need to be read alongside the works of less familiar authors such as William Warburton, Isaac de Lapeyrère and Martino Martini. Some of these men are well known in accounts of the origins of other disciplines (Egyptology, for example), while some have fallen into obscurity. By rescuing them from oblivion and reconstructing the character of their original concerns, Rossi traces the contours of a fascinating and alien map of knowledge.

The Dark Abyss of Time looks particularly closely at those who maintained the authority of scripture against Hobbists, atheists, sceptics, pre-Adamites and others ready to use new empirical findings to undermine religious certainty and the social fabric. Discussion of these "defence mechanisms" is divided into three parts, devoted respectively to Earth history, human history, and barbarism and language. Rossi is especially concerned to show how each of these topics became entwined in the making of a single major text in early modern intellectual history, Giambattista Vico's Nuova Scienza, published in its final form in 1744. Usually hailed as a founding figure of historicism and a precursor of Benedetto Croce, Vico appears here in dialogue with contemporary figures and themes. With scholarly finesse, Rossi depicts the author of the Nuovo Scienza picking his way "across the scorching hot, difficult terrain" of controversies about the origin of man and the Earth. Far from being an isolated forerunner, Vico can be seen charting a new path through territory that had been an intellectual battleground for decades.

This is an impressively researched book, but one with very few concessions to students or non-specialist readers. (A good introduction is available in the first two chapters of Martin J. S. Rudwick's Meaning of Fossils, recently reissued in paperback.) Some of the difficulties are simply a matter of style, especially as the analysis has a tendency to loose momentum in lengthy summaries of cosmological theories. Individual chapters are not clearly connected, and have something of the character of separate essays. Moreover, the main thrust of the argument is occasionally obscured by traces of the forward-looking disciplinary history that most of the book rightly questions. Chapters on Kelvin and the age of the Earth problem (and indeed, those on Buffon and James Hutton) seem especially out of place. The preface makes the real point of the book clear.

While placing Vico in a fresh perspective, Rossi has made a major foray into a vast and unexplored territory in the literature of early modern science, pointing a way that others will want to follow. At first glance, his book may seem to deal with a variety of subjects, many not obviously relevant to the history of science. As a result, there is a real danger that readers concerned with the development of a single discipline will turn only to those chapters that immediately interest them. Resist the temptation, for such an approach perpetuates precisely those intellectual blinkers that so frequently limit an appreciation of other ways of seeing the world.

James A. Secord is a Research Fellow at Churchill College, Cambridge CB3 ODS, UK. 